REVIEW

\title{
Serous effusions: diagnosis of malignancy beyond cyłomorphology. An analytic review
}

\author{
S K Mohanty, P Dey
}

Postgrad Med J 2003;79:569-574

In this brief review, the role of various ancillary techniques to detect malignancy in effusion fluid are evaluated and discussed. The data were collected from a large number of research articles published in various medical journals. The role of these techniques to increase the diagnostic accuracy in serous effusions is emphasised.

See end of article for authors' affiliations

Correspondence to:

Dr Pranab Dey

Department of 'Cytology, Post Graduate Institute of Medical, Education and Research, Chandigarh 160012, India; pranab@ sancharnet.in

Submitted 27 March 2003 Accepted 18 May 2003
$\mathrm{T}$ he cytological diagnoses of serous effusions are usually made by routine cytomorphology with certainty, allowing treatment decisions. Various studies have shown a sensitivity of $57.3 \%$ and specificity of $89 \%$ by conventional cytology for the detection of malignant cells in effusion samples. ${ }^{1}$ Studies have shown that positive and negative predictive values for detection of malignancy by cytomorphology are $89.3 \%$ and $69.4 \%$ respectively. However, a grey zone always exists, where the cytopathologist encounters problems in determining the nature of the cells whether reactive, atypical, or beyond doubt malignant. ${ }^{2}$ Therefore various ancillary techniques should be used to increase the diagnostic accuracy of malignancy in serous effusions. The various ancillary techniques and markers are:

- Immunocytochemistry.

- Electron microscopy.

- Argyrophilic nucleolar organiser region.

- Flow cytometry.

- Image morphometry.

- Cell proliferation indices.

- Tumour markers.

- Marker of metastasis.

- Immunofluorescence.

- Telomerase activity.

- Polymerase chain reaction.

- Fluorescent in situ hybridisation.

- Growth factors.

- Blood group antigens.

- HLA antigens.

- p53 oncogene product.

\section{IMMUNOCYTOCHEMISTRY}

The cytological differentiation of reactive mesothelial cells from adenocarcinoma metastatic to serosal membranes is often difficult. Although histochemical stains such as mucicarmine, periodic acid-Schiff with and without diastase digestion, and hyaluronidase alcian blue (or colloidal iron) stains are helpful, their usefulness is limited by their lack of specificity and sensitivity. ${ }^{3}$ Therefore immunocytochemcial analysis is the most commonly used technique and often involves the use of a panel of antibodies. There is a great volume of literature emphasising the value of immunocytochemistry in diagnosing mesothelioma from metastatic adenocarcinoma. Differences of opinion exist regarding which markers should be included in the routine diagnostic panel for differentiation of them. $^{5-9}$

The various markers expressed by adenocarcinoma include carcinoembryonic antigen, B72.3, Ber-Ep4, M0C-31, low molecular weight cytokeratins, and BG-8 anti-Lewisy. ${ }^{5-9} \mathrm{~A}$ diagnosis of metastatic adenocarcinoma is favoured if the neoplastic cells demonstrated immunoreactivity for the aforementioned markers; however, these markers are not distributed uniformly among different types of adenocarcinomas. Positive staining with at least two adenocarcinoma markers would favour the diagnosis. Therefore, a panel of antibodies is often used to confirm or to exclude the possibility of an adenocarcinoma. ${ }^{10}{ }^{11}$ Specific mesothelial cell markers include MEl monoclonal antibody, ${ }^{12}$ OV-CAR3, ${ }^{13}{ }^{14}$ thrombomodulin, ${ }^{15}$ HBME- $1,{ }^{15} \mathrm{~N}$-cadherin, ${ }^{16}$ and calre$\operatorname{tinin}^{17-20}$ In addition, mesotheliomas show positivity for both low and high molecular weight cytokeratins. ${ }^{21} 22$ The epithelial mesothelioma expresses thrombomodulin ranging from $49.1 \%$ to $100 \%$ positivity in different series. ${ }^{23-25}$ Similarly, Kl monoclonal antibody generated by immunising mice with the OV-CAR3 ovarian cell line, reacts with both epithelial and biphasic mesotheliomas. ${ }^{17}$ HBME-1 and mesothelial cell microvillus surface antigen are expressed by more than half of the mesothelial cells, however, more than half of adenocarcinomas also show similar immunoreactivity. ${ }^{12} \mathrm{~N}$-cadherin is immunoreactive with $77 \%$ of reactive mesothelial cells, $35 \%$ malignant mesotheliomas, and $48 \%$ of adenocarcinomas. ${ }^{16}$ Several investigators have demonstrated that calretinin is a sensitive and specific marker for both reactive and malignant mesothelial cells. But, unfortunately, scattered positive staining for calretinin is also reported in $5 \%$ to $10 \%$ of adenocarcinomas. ${ }^{26} 27$ Therefore, immunocytochemical profile of positive staining

Abbreviations: AgNOR, argyrophilic nucleolar organiser regions; EGP-2, epithelial glycoprotein-2; $M M P$, matrix metalloproteinases; NOR, nucleolar organiser regions; PCR, polymerase chain reaction; RT, reverse transcriptase; VEGF, vascular endothelial growth factor 
Table 1 Immunocytochemistry of mesothelioma and adenocarcinoma

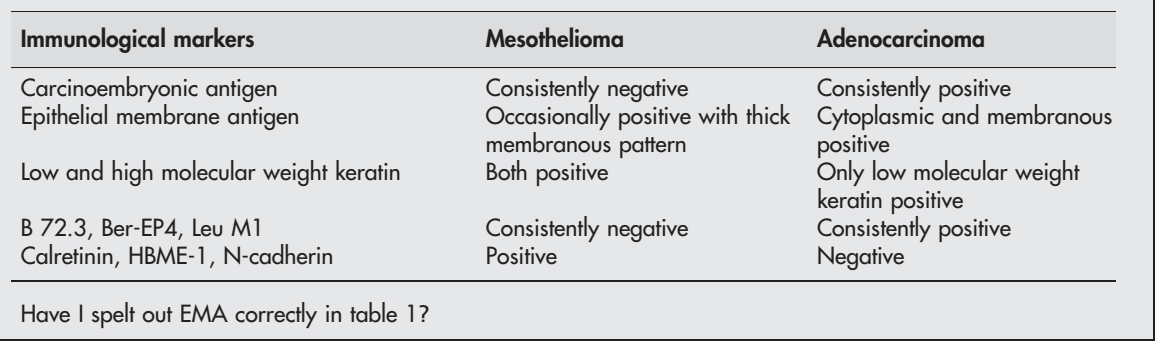

with any adenocarcinoma markers and negative staining with calretinin are specific and sensitive for recognising adenocarcinoma in fluid cytology. Table 1 summarises the positivity of different immunostaining for confirmation of mesotheliomas and adenocarcinomas.

\section{ELECTRON MICROSCOPY}

Ultrastructural examination of the mesothelioma cells show slender and bushy microvilli devoid of glycocalyceal bodies, evenly distributed around the entire cell surface, whereas in adenocarcinoma these are short and stubby with glycocalyceal bodies concentrated at poles. In addition, mesothelial cell shows tonofilaments surrounding the nucleus, abundant glycogen, and apical tight junctions with well developed desmosomes. ${ }^{28}$ However, electron microscopy is costly and adequate tissue for ultrastructural evaluation may not be available and the turnover time of electron microscope is quite lengthy. Furthermore, there may be overlapping features with adenocarcinoma and sometimes the interpretation may be difficult.

\section{ARGYROPHILIC NUCLEOLAR ORGANISER REGION}

The argyrophilic nucleolar organiser region (AgNOR) technique detects specialised nucleolar protein using a silver staining method. The number and size of NORs reflects cellular proliferation, activity, and transformation and may help to differentiate benign from malignant cells. AgNOR associated proteins have widespread application in diagnostic pathology. ${ }^{29}$ The reliability of this method in the evaluation of malignancy has been frequently demonstrated even by a simple visual assessment. ${ }^{3031}$ Thus, counting of AgNOR dots appears to be a very useful and simple way of obtaining data on the proliferative index of malignant as well as benign lesions. Various workers have applied this technique in serous effusions to detect malignancy. Sujathan et al have shown higher AgNOR counts in malignant cells, mean (SD) $4.72(0.76)$, compared with reactive mesothelial cells, mean (SD) $1.92(0.23)$, in serous effusion samples. ${ }^{32}$ In addition, the NORs are irregular in shape in cases of malignant cells, while these are larger and appear as single dots in reactive mesothelial cells. Subsequently, Rocher et al have shown significantly higher NOR counts in malignant cells, mean (SD) 13.78 (3.88), compared with reactive mesothelial cells, mean (SD) 4.88 (1.5). ${ }^{33}$ Later on Pomjanski et al compared the results of conventional cytomorphology, DNA image cytometry, immunocytochemistry, and AgNOR counts for the diagnosis of malignant cells in serous effusion. ${ }^{34}$ With the help of the AgNOR count, they detected $73 \%$ of malignant mesotheliomas on effusions.

\section{FLOW CYTOMETRY}

Flow cytometry has been a rapidly emerging technology over the last few decades. This expensive and sophisticated technology is being used increasingly from research laboratories to clinical laboratories. ${ }^{35-39}$ DNA flow cytometry requires single cells or nuclei in fluid suspension. The dissociated cells are stained with a DNA specific dye. These dyes bind with DNA stoichiometrically. The stained cells pass single in front of the laser beam. The cell absorbs the light and emits fluorescence, which is measured by flow cytometry with the help of a photomultiplier tube. The emitted fluorescence is proportional to the DNA content of the cells and is represented as a channel number, which is an arbitrary value depending on the machine's initial set up. The data are displayed as a DNA histogram. A DNA histogram thus obtained from the peripheral blood lymphocytes should show a single peak as all the cells contain 46 chromosomes $(2 \mathrm{n})$. Another small peak in double the channel number is also found, which represents the G2-M phase of cells. These cells contain $2 \times 46(4 \mathrm{n})$ chromosomes. The cells in between the two peaks usually represent the S-phase of the cell cycle. Any peak, other than these two peaks, should be considered as an aneuploid peak. DNA flow cytometry is commonly used for the diagnosis and prognosis of tumours. DNA aneuploidly and high S-phase (proliferative fraction) percentage are commonly noted in malignant tumours and may be used for diagnosis of malignancies. ${ }^{37} 39$

The technique of DNA flow cytometry has been used in effusion fluid by various workers to detect malignancy and showed wide variation in sensitivity and specificity. ${ }^{3640-42}$ Saha et al have shown 59\% sensitivity and 99\% specificity of flow cytometry in effusion samples, ${ }^{37}$ whereas Evans et al have shown $100 \%$ sensitivity and $86 \%$ specificity. ${ }^{43}$ The wide variation of sensitivity $(55 \%-100 \%)$ and specificity $(86 \%-$ $100 \%$ ) of DNA flow cytometry may be explained by the number of cases examined, types of cases included, criteria of aneuploidy, and various ways of processing of specimen for flow cytometry. Considerable admixtures of benign mesothelial cells with scanty malignant cells may create a problem in getting a prominent aneuploid peak. Dual colour multiparametric flow cytometry may be helpful to increase the sensitivity of flow cytometry. ${ }^{42}$

Flow cytometric determination of the percentage of natural killer lymphocytes can be useful to diagnose the metastatic effusion. Studies by Green and Griffin ${ }^{44}$ and Laurini et al ${ }^{45}$ have shown this as a quick procedure that appears to have a high sensitivity (100\%) and specificity $(96.8 \%)$ for the diagnosis of malignant effusions due to metastatic adenocarcinoma.

\section{IMAGE MORPHOMETRY}

Computerised image analysis can rapidly digitise the image of the cells and thereby can estimate various morphometric parameters of the cell. Cytological samples suitable for image can be obtained from smears, touch preparations, or cytocentrifuge. $^{46}$

The various cellular parameters that can be measured by image analysis include nuclear as well as cytoplasmic diameter, circumference, area, nuclear shape, ratio of nucleus to cytoplasmic area, chromatic texture, percentage positivity on immunocytochemistry, and optical density (sum optical density for DNA estimation by Feulgen stain). 
Compared with DNA flow cytometry, image cytometry is advantageous when the number of cells obtained for examination is limited. ${ }^{47}$ Cells can be selected in an automated fashion based on cellular characteristics. In a recent study, automatic cell differentiation was performed on cells stained by haematoxylin and eosin..$^{48}$ In this set up, cytoplasmic as well as nuclear features were used in the selection algorithm. In another study, Thunnissen et al examined the diagnostic value of DNA image cytometry for automatic cell selection in serosal fluid cytology. ${ }^{49}$ In that study $72 \%$ cases were aneuploid which were cytologically malignant, however, only $6 \%$ of the aneuploid cases had a cytological diagnosis of "atypia" and "suspicious for malignancy".

\section{PROLIFERATION MARKERS}

The diagnostic accuracy of malignant effusions can be improved by employing various cell proliferation markers. ${ }^{50}$ MIBl monoclonal antibody (Ki67) is present in cycling cells, but not in resting cells. Estimation of the percentage of cells reacting with Ki67 immunocytochemical staining can be performed counting 1000 cells on a consecutive high magnification field. ${ }^{51-53}$

Saleh et al have shown a statistically significant correlation between the Ki67 index and cytomorphology of benign (9\%), suspicious $(19 \%)$, and malignant $(28 \%)$ cells. ${ }^{50}$ However, cytomorphology should always remain the basis to differentiate benign from malignant serous effusions and Ki67 stain is a valuable adjunct in difficult cases, acting as a complementary tool to routine cytology.

\section{TUMOUR MARKERS}

Malignancies of any organ can metastasise to the serosal cavities, but the most common cancers concerned are lung and breast carcinomas, lymphoma, and less frequently, digestive and ovarian malignancies. ${ }^{54-56}$

Cytology alone has its limitations in certain cases in diagnosing malignancy. Many researchers have investigated the assay of tumour markers in effusion fluid in order to improve the diagnostic yield. ${ }^{54-56}$ Carcinoembryonic antigen has been extensively studied and has shown a diagnostic sensitivity of about $50 \%-60 \% .{ }^{57}$ Nevertheless, for a particular carcinoma, the use of a single tumour marker may be insufficient because it may not be uniformly expressed to detect all types of malignancies. Thus many studies emphasise the use of carcinoembryonic antigen along with various tumour markers such as carbohydrate antigens 15-3, 19-9, and 72-4. CYFRA $21-1$, a serum assay for soluble fragments of cytokeratin 19, has been recently proposed for the diagnosis and the follow up of non-small cell lung carcinoma, squamous cell carcinomas of the head and neck, uterine cervix, and bladder cancer. ${ }^{58-67}$ Salama et al have shown high values of this marker in the pleural fluid of patients with mesothelioma. ${ }^{68}$

\section{MARKER OF METASTASIS (CD44 AND CD44V ISOFORMS)}

CD44 is a widely distributed integral membrane protein that exists in a variety of forms with different molecular sizes ranging from $85 \mathrm{kD}$ to $160 \mathrm{kD} .^{69}{ }^{70}$ It acts as a receptor for hyaluronic acid and important in lymphocyte homing. ${ }^{71}$ CD44 isoforms are observed in epithelial malignancy with high metastatic potentials. The detection of malignant cells in serous effusions obtained from patients diagnosed with cancer indicates the presence of metastatic disease and furthermore is associated with poor biological outcome. Berner et al assessed the role of CD44s and Cd44v isoforms (CD44v3, v5, v6, v7, and v3-10) to distinguish mesothelial cells and malignant epithelial cells in effusions using immunocytochemical technique. ${ }^{72}$ The percentage immunoreactivity for CD44s was more in benign mesothelial cells $(94 \%)$ compared with malignant/atypical epithelial cells $(23 \%)$ and in contrast CD44v3-10 positivity was more in malignant/atypical cells (55\%) than benign cells (6\%). Therefore, as a marker of metastatic disease CD44s and CD44v isoforms, particularly CD44v3-10, can be used in a difficult situation.

\section{IMMUNOFLUORESCENCE}

The immunofluorescence double staining technique can be applied in malignant effusions to combine DNA measurement with those of immunocytochemical and ligand immunocytochemical reactivity. Kayser et al investigated potential disease and prognosis associated nuclear and cellular features from cell properties in a prospective study on malignant pleural effusion. ${ }^{73}$ They measured the integrated nuclear fluorescence, the expression of binding capacities of carrier immobilised oestradiol, progesterone, testosterone, sarcolectin, and the presence of calcyclin in 50 cases of proven malignant pleural effusion (10 mesotheliomas and 40 metastatic tumours pleural effusion). A significant correlation was obtained between the S-phase related tumour cell fraction and the expression of progesterone receptor.

\section{TELOMERASE ACTIVITY}

Telomeres are specialised structures at the ends of the chromosomes in eukaryotic cells. They are shortened with each cell division, finally resulting in cellular senescence. The enzyme, telomerase, a ribonuclear protein, compensates for telomeric loss. Telomerase is believed to play an important part in the evolution of various malignancies. A polymerase chain reaction (PCR) based method is used to determine telomerase activity. ${ }^{74}$ Telomerase activity has been demonstrated in various malignancies, which include gastric, breast, prostatic, cervical, and so on ${ }^{75-79}$ In pleural effusions, telomerase activity was detected in $52 \%-91 \%$ of specimens diagnosed as malignant in routine cytology. ${ }^{80-83}$ However, Dejmek et al have shown telomerase activity in $67 \%$ cases of malignant effusion. ${ }^{84}$ Telomerase is found to be one of the promising markers of malignancy, however, the reactive atypical cells also show nuclear fluorescence. In this situation, the cells strongly suspicious for malignancy on cytology should be taken into account.

\section{POLYMERASE CHAIN REACTION}

The PCR enables exponential amplification of DNA or RNA sequences enhancing diagnostic sensitivity and specificity using specific primer. ${ }^{85}$

Sakaguchi et al developed a sensitive and specific method for the detection of epithelial malignancy with a two stage molecular based assay that combined enrichment for cancer cells by immunomagnetic bead selection and reverse transcriptase (RT)-PCR detection of epithelial glycoprotein-2 (EGP-2) RNA. ${ }^{86}$ In their study, 110 cases of pleural and peritoneal effusions ( 30 from patients with known carcinoma and 80 from those without known carcinoma) were taken and the results were compared with cytomorphological features. Out of 18 cytologically positive or suspicious effusions, 17 (94\%) were positive for EGP-2 RNA. The one negative sample was from a patient who had recently received combination chemotherapy. Of the 92 cytologically negative samples, 11 (12\%) were positive for EGP-2. Therefore, this method appears to be highly specific and sensitive in detecting malignant cells and may be useful as an adjunct to routine cytomorphological examination. Davidson et al have analysed mRNA expression of matrix metalloproteinases (MMP) membrane type 1, 2, and 3 in serous effusions of patients with ovarian malignancies using the 
RT-PCR reaction. ${ }^{87}$ In addition they also evaluated membrane type 1 MMP expression in effusions in primary and metastatic lesions using mRNA in situ hybridisation. Membrane type 1 MMP was localised to tumour cells in 32 of 85 primary and metastatic solid lesions, and stromal cells expressed membrane type 1 MMP in three cases.

\section{FLUORESCENCE IN SITU HYBRIDISATION}

In recent years interphase cytogenetics by fluorescence in situ hybridisation (FISH) has been used in clinical pathology to delineate chromosomal aberrations in neoplasia. ${ }^{88} \mathrm{FISH}$ is a powerful tool for genetic evaluation and permits microscopic identification, localisation of aberrations in interphase as well as metaphase of the cell cycle. Fiegl et al in their study have shown the role of FISH in detecting the malignant cells in effusion fluid from patients with carcinoma. ${ }^{89}$ Their study included 201 effusions from patients with advanced cancer, along with nine with a primary breast tumour. They have used various centromeric probes to determine the malignancy associated changes.

Subsequently, another study has shown a hyperdiploid cell population in pleural effusion fluid using dual coloured FISH. $^{90}$ Therefore, the FISH technique can be used in effusions along with cytology to detect the aneuploid cells indicating malignancies.

\section{GROWTH FACTORS}

Vascular endothelial growth factor (VEGF) is an important mediator of angiogenesis. Zebrowski et al have shown significantly higher VEGF levels in malignant pleural effusion by using an immunoassay. ${ }^{91}$ Yanagawa et al have shown a significantly higher amount of VEGF by enzyme immunoassay in cytologically proven malignant pleural effusions associated with primary lung cancer than in those with benign exudative pleural effusions. ${ }^{92}$ However, none of these studies has highlighted the role of VEGF in differentiating metastatic effusion from mesothelioma.

Lysophosphatidic acid and sphingosine-1-phosphate are bioactive phospholipids with mitogenic and growth factorlike activity. They act through a specific cell surface receptor, which is located in many normal as well as transformed cells. Lysophosphatidic acid has recently been implicated as a growth factor in ovarian cancer patients in effusions. ${ }^{93}$ Westermann et al postulated a role of lysophosphatidic acid-like lipids in the peritoneal spread of ovarian cancer and possibly that of other predominantly intraperitoneal malignancies. ${ }^{93}$

\section{BLOOD GROUP ANTIGENS}

Sialosyl-Tn is an aberrantly glycosylated precursor of the MN blood group antigen frequently expressed in carcinomas and dysplastic epithelium. This can be assessed by solid phase immunoradiometric assay and immunocytochemistry. Zimmerman et al showed that sialosyl-Tn may have diagnostic value in discriminating carcinoma cells from reactive mesothelial cell in serous effusions. ${ }^{94}$ They studied sialosyl-Tn immunocytochemistry on cell block material from 72 serous effusion samples. The immunoreactivity was strong in carcinoma $(77 \%)$ cases compared with moderate to weak staining in benign $(4 \%-18 \%)$ cases. The sensitivity and specificity values of sialosyl-Tn immunostaining were 100\% and $78 \%$ whereas the positivity and negative predictive values were $100 \%$ and $76 \%$ respectively.

\section{ROLE OF HLA ANTIGENS}

Magyarosy et al showed significant paucity of HLA-1 antigens on metastatic carcinoma cells in effusion fluid, whereas the reactive mesothelial cells showed uniformly strong positivity for both HLA-1 and $\beta_{2}$-microglobulin. ${ }^{95}$ Various metastatic carcinoma cells can be identified in effusion fluids by appropriate immunocytochemical stains.

\section{ONCOGENE PRODUCT}

p53 is a nuclear phosphoprotein that appears to play an important part in regulating cell death by apoptosis and thereby net cell increment. ${ }^{96}$ It is well accepted that wild type p53 protein acts as a "tumour suppressor" in normal cells. Mutation of the p53 tumour suppressor gene occurs frequently in mesotheliomas, ${ }^{97} 98$ lung, ${ }^{99} 100$ and colonic carcinomas. ${ }^{101}$ Mutated forms of p53 have a longer half life than wild type p53 and therefore accumulated in the nucleus. This mutated p53 is readily detectable by immunohistochemical methods. ${ }^{102} 103$ Various studies have shown that p53 immunostaining on effusion can detect $50 \%-55 \%$ of malignancies in effusion. ${ }^{102}{ }^{103}$ Benign cells are negative for $\mathrm{p} 53$ immunostaining. Various authors have concluded that p53 immunostaining is highly specific and moderately sensitive marker of malignancy in effusion fluid. ${ }^{102-104}$

Table 2 Salient features of different ancillary tests

\begin{tabular}{|c|c|}
\hline Ancillary tests & Features \\
\hline Immunocyłochemistry & $\begin{array}{l}\text { Commonly used } \\
\text { Panel of antibody is needed } \\
\text { High sensitivity and specificity } \\
\text { Cost effective }\end{array}$ \\
\hline Electron microscopy & $\begin{array}{l}\text { Costly } \\
\text { Long turnover time } \\
\text { Helpful to distinguish mesothelioma } \\
\text { and adenocarcinoma }\end{array}$ \\
\hline AgNOR & $\begin{array}{l}\text { Simple and easy to do } \\
\text { Cheap } \\
\text { Have potential value }\end{array}$ \\
\hline Flow cytometry & $\begin{array}{l}\text { Costly } \\
\text { Variable sensitivity } \\
\text { Diploid pattern does not rule out } \\
\text { malignancy and rarely benign cells show } \\
\text { aneuploidy } \\
\text { Dual colour flow cytometry more helpful }\end{array}$ \\
\hline Image cytometry & $\begin{array}{l}\text { Visual light microscopic selection of cell possible } \\
\text { Slow and tedious } \\
\text { Laser scanning image cytometry is rapid }\end{array}$ \\
\hline Proliferative markers & $\begin{array}{l}\text { High Ki67 index is an excellent } \\
\text { marker to recognise rapidly proliferating } \\
\text { cell population indicating malignancy }\end{array}$ \\
\hline Tumour markers & Helpful in selective tumours to diagnose \\
\hline Markers of metastasis & $\begin{array}{l}\text { CD44v 3-10 positivity may be helpful } \\
\text { in difficult situation }\end{array}$ \\
\hline Immunofluorescence & $\begin{array}{l}\text { Experimental stage } \\
\text { Integrated nuclear fluorescence of oestradiol anc } \\
\text { progesterone may be helpful }\end{array}$ \\
\hline Telomerase activity & $\begin{array}{l}\text { Demonstration of telomerase activity may indicate } \\
\text { malignancy }\end{array}$ \\
\hline PCR & $\begin{array}{l}\text { Detection of EGP-2RNA by RT-PCR is } \\
\text { specific and sensitive }\end{array}$ \\
\hline FISH & $\begin{array}{l}\text { Minor chromosomal aberration can be detected } \\
\text { No chromosomal culture needed }\end{array}$ \\
\hline Growth factor & $\begin{array}{l}\text { VEGF, an indicator of angiogenesis, } \\
\text { is significantly higher in malignant effusion }\end{array}$ \\
\hline Blood group antigen & $\begin{array}{l}\text { Sialosysl-Tn expressed in carcinomas } \\
\text { High sensitivity and moderate specificity }\end{array}$ \\
\hline p53 & $\begin{array}{l}\text { Mutant type p53 is demonstrable in malignant } \\
\text { cells } \\
\text { High specificity but low sensitivity }\end{array}$ \\
\hline
\end{tabular}


Table 2 summarises the salient features of different ancillary techniques to identify malignancy in effusion fluid. The judicious application of these techniques is needed to increase the diagnostic accuracy and to make a decision. Many of these techniques are at an experimental level and quite promising. Furthermore the cost effectiveness of these techniques should also be taken into consideration for their future application in a clinical laboratory.

\section{Authors' affiliations}

S K Mohanty, P Dey, Department of Cytology, Post Graduate Institute of Medical Education and Research, Chandigarh, India

\section{REFERENCES}

1 Thunnissen FB, Peterse JL, van Pel R, et al. Reliability of fine needle aspiration cytology for distinguishing between carcinoma, lymphoma and sarcoma: the influence of clinical information. Cytopathology 1993;4:107-14.

2 Motherby $\mathbf{H}$, Nadjari B, Friegel $P$, et al. Diagnostic accuracy of effusion cytology. Diagn Cytopathol 1999;20:350-7.

3 Hammar SP, Bockus DE, Remington FL, et al. Mucin-positive epithelial mesotheliomas: a histochemical, immunohistochemical, and ultrastructural comparison with mucin-producing pulmonary adenocarcinomas. Ultrastruct Pathol 1996;20:293-325

4 Roggli VL, Kolbeck J, Sanfilippo F, et al. Pathology of human mesothelioma: etiologic and diagnostic considerations. Pathol Annu 1987;22(pt 2):91-131.

5 Wang NS. Electron microscopy in the diagnosis of pleural mesotheliomas. Cancer 1973;31:1046-54.

6 Warhol MJ, Hickey WF, Corson JM. Malignant mesothelioma: intrastructural distinction from adenocarcinoma. Am J Surg Pathol 1982;6:307-14.

7 Esteban MJ, Yokota S, Husain S, et al. Immunocytochemical profile of benign and carcinomatous effusions: a practical appraoch to difficult diagnosis. Am J Clin Pathol 1990;94:698-705.

8 Cibas ES, Corson JM, Pinkus GS. The distinction of adenocarcinoma from malignant mesothelioma in cell blocks of effusions: the role of routine mucin histochemistry and immunohistochemical assessment of carcinoembryonic antigen, keratin proteins, epithelial membrane antigen, and milk fat globulederived antigen. Hum Pathol 1987; 18:67-74.

9 Mason MR, Bedrossian CW, Fahey CA. Value of immunocytochemistry in the study of malignant effusions. Diagn Cytopathol 1987;3:215-21

10 Silverman JF, Nance K, Phillips B, et al. The use of immunoperoxidase panels for the cytologic diagnosis of malignancy in serous effusions. Diagn Cytopathol 1987;3:134-40.

11 Nance KV, Silverman JF. Immunocytochemical panel for the identification of malignant cells in serous effusions. Am J Clin Pathol 1991;95:867-74.

12 Skov BG, Stahel RA, Hirsch F. ME1-antibody labelling of primary bronchogenic tumors and extrapulmonary malignancies. Lung Cancer 1994; 11:221-7.

13 Chang K, Pastan I, Willingham MC. Frequent expression of the tumor antigen CAK1 in squamous-cell carcinomas. Int J Cancer 1992;51:548-54.

14 Chang K, Pai LH, Pass $\mathrm{H}$, et al. Monoclonal antibody K1 reacts with epithelial mesothelioma but not with lung adenocarcinoma. Am J Surg Pathol 1992; 16:259-68.

15 Fetsch PA, Abati A, Hijazi YM. Utility of the antibodies CA 19-9, HBME-1, and thrombomodulin in the diagnosis of malignant mesothelioma and adenocarcinoma in cytology. Cancer 1998;84:101-8.

16 Simsir A, Fetsch P, Mehta D, et al. E-cadherin, N-cadherin, and calretinin in pleural effusions: the good, the bad, the worthelss. Diagn Cytopathol 1999;20:125-30

17 Delahaye M, Hoogsteden HC, Van der Kwast TH. Immunocytochemistry of malignant mesothelioma: OV632 as a marker of malignant mesothelioma. J Pathol 1991;165:137-43.

18 Donna A, Betta PG, Bellingeri D, et al. Cytologic diagnosis of malignant mesothelioma in serous effusions using an antimesothelial-cell antibody (published correction appears in Diagn Cytopathol 1992;8:661). Diagn Cytopathol 1992;8:361-5.

19 Clark SP, Chou ST, Martin TJ, et al. Parathyroid hormone-related protein antigen localization distinguishes between mesothlioma and adenocarcinoma of the lung. J Pathol 1995;176:161-5.

20 Ko EC, Jhala NC, Shultz JJ, et al. Use of a panel of markers in the differential diagnosis of adenocarcinoma and reactive mesothelial cells in fluid cytology. Am J Clin Pathol 2001;116:709-15.

21 Blobel GA, Moll R, Franke WW, et al. The intermediate filament cytoskeleton of malignant mesotheliomas and its diagnostic significance. Am J Pathol 1985;121:235-47.

22 Ordonez NG. Value of cytokeratin 5/6 immunostaining in distinguishing epithelial mesothelioma of the pleura from lung adenocarcinoma. Am J Surg Pathol 1998;22:1215-21.

23 Ascoli V, Scalzo CC, Taccongna S, et al. The diagnostic value of thrombomodulin immunolocalization in serous effusions. Arch Pathol Lab Med 1995:119:1136-40.

24 Kennedy AD, King G, Kerr KM. HBME-1 and antithrombomodulin in the differential diagnosis of mesothelioma of pleura. J Clin Pathol 1997; 50:859-62.

25 Kondi-Paphitis A, Addis BJ. Secretotry component in pulmonary adenocarcinoma and mesothelioma. Histopathology 1986;10:1279-87.
26 Doglioni C, Tos AP, Laurino L, et al. Calretinin: a novel immunocytochemical marker for mesothelioma. Am J Surg Pathol 1996;20:1037-40.

27 Leers MP, Aarts MM, Theunissen PH. E-cadherin and calretinin: a useful combination of immunochemical markers for differentiation between mesothelioma and metastatic adenocarcinoma. Histopathology 1998;32:209-16.

28 Bedrossian CWM, Bonsib S, Moran C. Differential diagnosis between mesothelioma and adenocarcinoma: a multimodal approach based on ultrastructure and immunocytochemistry. Semin Diagn Pathol 1992:9:124-40

29 Ploten D, Menager $M$, Jeannesson $P$, et al. Improvement of the staining and visualization of the argyrophilic proteins of the nucleolar organizer region at optical level. Histochem J 1986;18:5-14.

30 Eskelinem MJ, Lipponen PC, Collan Y, et al. The role of nuclear organizer regions as prognostic factors in breast cancer. Eur J Cancer $1991 ; 27: 989-92$.

31 Mourad WA, Erkman Balis B, Livingstone S, et al. Arygrophilic nucleolar organizer regions in breast carcinoma: correlation with DNA flow cytometry, histopathology and lymph node status. Cancer 1992;69:1739-44.

32 Sujathan K, Kannan S, Pillai KR, et al. Significance of AgNOR count in differentiating malignant cells from reactive mesothelial cells in serious effusions. Acta Cytol 1996:40:724-8

33 Rocher AE, Blanco AM, Palaoro LA. Usefulness of AgNOR technique in the interpretation of serous effusions. Rev Med Chil 2000;128:963-8.

34 Pomjanski N, Motherby H, Buckstegge B, et al. Early diagnosis of mesothelioma in serous effusions using AgNOR analysis. Anal Quant Cytol Histol 2001;23:151-60.

35 Cibas ES. Application of flow cytometric DNA analysis to diagnostic cytology. Diagn Cytopathol 1995;13:166-71.

36 O'Leary TJ. Flow cytometry in diagnostic cytology. Diagn Cytopathol 1998; 18:41-6

37 Saha I, Dey P, Vohra H, et al. Role of DNA flow cytometry and image cytometry on effusion fluid. Diagn Cytopathol 2000;22:81-5.

38 Saikia UN, Dey P, Vohra H, et al. DNA flow cytometry of non-Hodgkin's Lymphomas: correlation with cytologic grade and clinical relapse. Diagn Cytopathol 2000;22:153-6.

39 Kumar UN, Dey P, Mondal AK, et al. DNA flow cytometry and bladder irrigation cytology in detection of bladder carcinoma. Diagn Cytopathol 2001;24:153-6.

40 Joensuu H, Klemi PJ, Eerola E. Diagnostic value of flow cytometric DNA determination combined with fine needle aspiration biopsy in thyroid tumors. Anal Quant Cytol Histol 1987;9:328-34.

41 Zabro RJ. Flow cytometric DNA analysis of effusions. Am J Clin Pathol 1991;95:2-4

42 Joseph MG Baneriee D, Harri P, et al. Multiparameter flow cyłometric DNA analysis of effusions: a prospective study of 36 cases compared with routine cytology and immunohistochemistry. Mod Pathol 1995;8:686-93.

43 Evans D, Thornthwaite J, Ng ABP, et al. DNA flow cytometry of pleural effusions: comparison with pathology for the diagnosis of malignancy. Anal Quant Cytol Histol 1982;5:19-27.

44 Green LK, Griffin J. Increased natural killer cells in fluids. A new, sensitive means of detecting carcinoma. Acta Cytol 1996;40:1240-5.

45 Laurini JA, Garcia A, Elsner B, et al. Relation between natural killer cells and neoplastic cells in serous fluids. Diagn Cytopathol 2000;22:347-50.

46 Walb WA, Rainer RO, Memoli VA. Basic principles of image processing. Am J Clin Pathol 1992;98:493-501.

47 Schneller J, Eppich E, Greenebaum E, et al. Flow cytometry and Feulgen cytophotometry in evaluation of effusions. Cancer 1987;59:1307-13.

48 Maringer T, Gschwendtner A, Toetsch M, et al. Automated cell differentiation of bronchoalveolar lavage samples with two-step image analysis. Anal Quant Cytol Histol 1996; 18:453-60.

49 Thunnissen FB, Buchholtz RT, Woutersen DP, et al. Clinical value of DNA image cytometry in effusions with atypia. Diagn Cytopathol 1999:21:112-16.

50 Saleh H, Bober P, Tabaczka P. Value of Ki67 immunostain in identification of malignancy in serous effusions. Diagn Cytopathol 1999;20:24-8.

51 Sahin AA, Ro JY, Brown RW, et al. Assessment of Ki67-derived tumor proliferative activity in colorectal adenocarcinoama. Mod Pathol 1994;7:17-22.

52 Esteban JM, Sheibani K. DNA ploidy analysis of pleural mesothelioma: its usefulness for their distinction from lung adenocarcinoma. Mod Pathol 1992:5:626-31

53 Dalquen $\mathrm{P}$, Baschiera B, Chaffard R, et al. MIB1 (Ki67) immunostaining of breast cancer cells in cytology smears. Acta Cytol 1997;41:229-32.

54 Sahn SA. The pleura. Am Rev Respir Dis 1988;138:184-234.

55 Serre G, Daste G, Vincent C, et al. Diagnostic approach to the patient with pleural effusions: cytologic analysis of pleural fluid. In: Deslauriers J, Lacquet UK, eds. International trends in general thoracic surgery. St Louis: Mosby, 1990;6:35-45

56 Fenton KN, Richardson JD. Diagnosis and management of malignant pleura effusions. Am J Surg 1995:170:69-74.

57 Piantino $\mathrm{P}$, Cellerino A. Tumor markers determination in extrahematic fluids. J Nucl Med Allied Sci 1990;34:128-36.

58 Ferroni P, Szpak C, Greiner JW, et al. CA72-4 radioimmunoassay in the diagnosis of malignant effusions. Comparison of various tumor markers. Int J Cancer 1990:46:445-51.

59 Villena V, Lopez-Encuentra A, Echave-Sustaeta J, et al. Diagnostic value of CA72-4, carcinoembryonic antigen, CA15-3 and CA19-9 assay in pleural fluid. A study of 207 patients. Cancer 1996;78:736-40

60 Soletormos G, Nielsen D, Schioler V, et al. Tumor markers cancer antigen 15.3, carcinoembryonic antigen, and tissue polypeptide antigen for 
monitoring metastatic breast cancer during first-line chemotherapy and follow-up. Clin Chem 1996;42:564-75.

61 Spila A, Cavaliere F, Casaldi V, et al. CA72-4 serum marker-a new tool in the management of carcinoma patient. Cancer Invest 1995; 13:227-38.

62 Grem J. The prognostic importance of tumor markers in adenocarcinoma of the gastrointestinal tract. Curr Opin Oncol 1997;9:380-7.

63 Pujol JL, Grenier J, Daures JP, et al. Serum fragment of cytokeratin subunit 19 measured by CYFRA 21-1 immunoradiometric assay as a marker of lung cancer. Cancer Res 1993;53:61-6.

64 Plebani M, Basso D, Navagila P, et al. Clinical evaluation of seven tumor markers in lung cancer diagnosis: can any combination improve the results? Br J Cancer 1995;72:170-3.

65 Doweck I, Barak M, Greenberg E, et al. Cyfra21-1. A new potential tumor marker for squamous cell carcinoma of head and neck. Arch Otolaryngol Head Neck Surg 1995;121:177-81.

66 Callet N, Cohen-Solal Le Nin CC, Berthelot E, et al. Cancer of the uterine cervix: sensitivity and specificity of serum Cyfra21.1 determination. Eur J Gynecol Oncol 1998;19:50-6.

67 Morita T, Kikuchi T, Hashimoto S, et al. Cytokeratin-19 fragment (CYFRA211) in bladder cancer. Eur Urol 1997;32:327-44.

68 Salama G, Miedouge M, Rouzaud P, et al. Evaluation of pleural CYFRA21-1 and carcinoembryonic antigen in the diagnosis of malignant pleural effusions. Br J Cancer 1998:77:472-6.

69 Gallatin WM, Rosenman SJ, Ganji A, et al. Structure-function relationship of CD44 class of glycoproteins. Cell Mol Mech Inf 1991;2:131-50.

70 Picker LJ, Nakache M, Butcher EC. Monoclonal antibodies to human lymphocyte homing receptors define a novel class of adhesion molecules in on diverse cell types. J Cell Biol 1989;109:927-37.

71 Culty M, Miyaka K, Kincade PW, et al. The hyaluronate receptor is a member of CD44 (H-CAM) family of cell surface glycoproteins. J Cell Biol 1990;111:2765-74.

72 Berner HS, Davidson B, Berner A, et al. Differential expression of CD44s and CD44v3-10 in adenocarcinoma cells in effusions. Virchows Arch 2000;436:330-5.

73 Kayser K, Markle C, Kugler C, et al. Integrated nuclear fluorescence and expression of hormone-binding sites in malignant pleural effusions. Anal Quant Cytol Histol 2000;22:364-74.

74 Kim NW, Piatyszek MA, Prowse KR, et al. Specific association of human telomerase activity with immortal cells and cancer. Science 1994;226:2011-15.

75 Hiyama E, Yokoyama T, Tatsumoto $\mathrm{N}$, et al. Telomerase activity in gastric cancer. Cancer Res 1995;55:3258-62.

76 Hiyama K, Hiyama E, Ishioka S, et al. Telomerase activity in small cell and non-small cell lung cancer. J Natl Cancer Inst 1995;87:895-902.

77 Hiyama E, Gollahon L, Kotaoka T, et al. Teleomerase activity in human breast tumors. J Natl Cancer Inst 1996:88:116-22.

78 Sommerfeld H-J, Meeker AK, Piatyszek MA, et al. Telomerase activity: a prevalent marker of malignant human prostate tissue. Cancer Res 1996;56:218-22.

79 Anderson S, Shera K, Ihle J, et al. Telomerase activation in cervical cancer. Am J Pathol 1997;151:25-31.

80 Cunningham VJ, Markham N, Shroyer AL, et al. Detection of telomerase expression in fine-needle aspirations and fluids. Diagn Cytopathol 1998;18:431-6.

81 Mu XC, Brien TP, Ross JS, et al. Telomerase activity in benign and malignant cytologic fluids. Cancer 1999;25(87):93-9.

82 Toshima S, Arai T, Yasuda Y, et al. Cytological diagnosis and telomerase activity of cells in effusions of body cavities. Oncol Rep 1999;6:199-203.
83 Yang CT, Lee MH, Lan RS, et al. Telomerase activity in pleural effusions: diagnostic significance. J Clin Oncol 1998;16:567-73.

84 Dejmek A, Yahata N, Ohyashiki K, et al. In situ telomerase activity in pleural effusions: a promising marker for malignancy. Diagn Cytopatho 2001;24:11-15.

85 Eisenstein $\mathbf{B}$. The polymerase chain reaction: a new method of using molecular genetics for medical diagnosis. N Eng J Med 1990;322:178-82.

86 Sakaguchi M, Virmani AK, Ashfaq R, et al. Development of a sensitive, specific reverse transcriptase polymerase chain reaction-based assay for epithelial tumor cells in effusions. Br J Cancer 1999;79:416-22.

87 Davidson B, Goldberg I, Berner A, et al. Expression of membrane-type 1, 2, and 3 matrix metalloproteinases messenger RNA in ovarian carcinoma cells in serous effusions. Am J Clin Pathol 2001;115:517-24.

88 Wolman SR. Fluorescence in situ hybridization: a new tool for the pathologist. Hum Pathol 1994;25:586-90.

89 Fiegl M, Kaufmann H, Zojer N, et al. Malignant cell detection by fluorescence in situ hybridization (FISH) in effusions from patients with carcinoma. Hum Pathol 2000;31:448-55.

90 Jia D, Zhang Z, Liu S, et al. Study on interphase cytogenetic abnormalities in malignant cells in pleural fluids from lung cancer cases. Zhonghua $Y_{i} X_{u e} Y_{i}$ Chuan Xue Za Zhi 2000;17:244-7.

91 Zebrowski BK, Yano S, Liu W, et al. Vascular endothelial growth factor levels and induction of permeability in malignant pleural effusions. Clin Cancer Res 1999;5:3364-8.

92 Yanagawa H, Takeuchi E, Suzuki Y, et al. Vascular endothelial growth factor in malignant pleural effusion associated with lung cancer. Cancer Immunol Immunother 1999;48:396-400.

93 Westermann AM, Harik E, Postma FR, et al. Malignant effusions contain lysophosphatidic acid (LPA)-like activity. Ann Oncol 1998;9:437-42.

94 Zimmerman RL, Fogt F, Bibbo M. Diagnostic utility of sialosyl-Tn in discriminating carcinomatous cells from benign mesothelium in body cavity effusions. Acta Cytol 1999;43:1079-84.

95 Magyarosy E, Martin WJ, Chu EW, et al. Differential diagnostic significance of the paucity of HLA-I antigens on metastatic breast carcinoma cells in effusions. Pathol Oncol Res 1999;5:32-5.

96 Levine AJ, Momand J, Finlay CA. The p53 tumor suppressor gene. Nature 1991;351:453-6.

97 Cote RJ, Jhanwar SC, Novick S, et al. Genetic alterations of the p53 gene are a feature of malignant mesotheliomas. Cancer Res 1991;51:5410-16.

98 Kafiri G, Thomas DM, Shepard NA, et al. P53 expression is common in malignant mesothelioma. Histopathology 1992;21:331-4.

99 Bennett WP, Borkowski A, Colby TV, et al. P53 mutation and immunopositivity in the pathogenesis of human bronchogenic carcinomas (abstract). Lab Invest 1993;68:129A.

100 Bodner SM, Minna JD, Jensen SM, et al. Expression of mutant p53 protein in lung cancer correlates the class of p53 gene mutation. Oncogene 1992:7:743-9.

101 Rodrigues N, Rowan A, Smith MEF, et al. P53 mutations in colorectal cancer. Proc Natl Acad Sci U S A 1990;87:7555-9.

102 Mullick SS, Green LK, Ramzy I, et al. P53 gene product in pleural effusions: practical use in distinguishing benign from malignant cells. Acta Cytol 1996;40:855-60.

103 Mayall F, Heryet A, Manga D, et al. p53 immunostaining is a highly specific and moderately sensitive marker of malignancy in serous fluid cytology. Cytopathology 1997;8:9-12.

104 Zoppi JA, Pellicer EM, Sundblad AS. Diagnostic value of $\mathrm{p} 53$ protein in the study of serous effusions. Acta Cytol 1995;39:721-4. 